BMJ Paediatrics Open

\title{
Improving communication between staff and disabled children in hospital wards: testing the feasibility of a training intervention developed through intervention mapping
}

\author{
Rebecca Gumm, ${ }^{1}$ Eleanor Thomas, ${ }^{1}$ Claire Lloyd, ${ }^{2}$ Helen Hambly, ${ }^{2}$ \\ Richard Tomlinson, ${ }^{1}$ Stuart Logan, ${ }^{2}$ Christopher Morris ${ }^{2}$
}

To cite: Gumm R, Thomas $E$, Lloyd C, et al. Improving communication between staff and disabled children in hospital wards: testing the feasibility of a training intervention developed through intervention mapping. BMJ Paediatrics Open 2017;1:e000103. doi:10.1136/ bmjpo-2017-000103

- Additional material is published online only. To view please visit the journal online (http://dx.doi.org/10.1136/ bmjpo-2017-000103).

Received 26 May 2017 Revised 14 August 2017 Accepted 21 August 2017

\section{(a) CrossMark}

${ }^{1}$ Department of Child Health, Royal Devon and Exeter NHS Foundation Trust, Exeter, Devon, UK

${ }^{2}$ PenCRU (Peninsula Cerebra Research Unit) and PenCLAHRC, Institute of Health Research, University of Exeter Medical School, Exeter, UK

Correspondence to Dr Christopher Morris; christopher.morris@exeter.ac.uk

\section{ABSTRACT}

Objective To develop and test the feasibility of a novel parentinspired training intervention for hospital ward staff to improve communication with disabled children when inpatients.

Design Training content and delivery strategies were informed by the iterative process of Intervention Mapping and developed in collaboration with parents of disabled children.

Setting UK University Hospital children's ward.

Subjects 80 medical, nursing, allied health professionals, clerical and housekeeping staff on a children's ward.

Methods Themes identified in previous qualitative research formed the basis of the training. Learning objectives included prioritising communication, cultivating empathy, improving knowledge and developing confidence. Participant feedback was used to refine content and delivery. Intervention documentation adheres to the Template for Intervention Description and Replication checklist.

Results Highlighting mandated National Health Service policies and involving the hospital Patient and Carer Experience Group facilitated management support for the training. Eighty staff participated in one of four 1-hour sessions. A paediatric registrar and nurse delivered sessions to mixed groups of staff. General feedback was very positive. The intervention, fully documented in a manual, includes videos of parent carers discussing hospital experiences, interactive tasks, small group discussion, personal reflection and intention planning. Generic and local resources were provided.

Conclusion It was feasible to deliver this new communication training to hospital ward staff and it was positively received. Early feedback was encouraging and indicates a commitment to behaviour change. Further piloting is required to establish the transferability of the intervention to other hospitals, followed by consideration of downstream markers to evaluate the effects on disabled children's inpatient experience. Organisational and cultural change is required to support individual behaviour change.

\section{INTRODUCTION}

Disabled children should be consulted about their care and decisions that affect them, a right asserted by The UN Conventions on

\section{What is already known on this topic?}

Disabled children are admitted to hospital more often than other children.

- Research suggests that disabled children's experience as inpatients is not always optimal and identifies communication between staff, children and families as a key issue.

- Improving children's experience of healthcare is a priority for the National Health Service.

\section{What this study hopes to add?}

- We describe development of a novel training using the intervention mapping approach.

- The training comprises videos of parent carers discussing hospital experiences, interactive tasks, small group discussion, personal reflection and intention planning.

- The training was feasible and is documented in a manual to enable replication.

the Rights of the Child ${ }^{1}$ and the Rights of Persons with Disabilities. ${ }^{2}$ The UK is a signatory to both conventions and National Health Service (NHS) policy affirms that children have the right to be treated with respect and enabled to make decisions about their healthcare. ${ }^{3}$ Despite legislation and policy at international and national level to promote equitable healthcare, the practical reality is that poorer experiences are still reported for disabled children. ${ }^{4}$ This is particularly evident with regards to disabled children and their involvement in decision-making processes for their own healthcare and well-being. The NHS has committed to improve patient experience of care through the NHS Outcomes Framework and identified responsiveness to 
inpatients' needs as an indicator to evaluate improvement. $^{5}$

Disabled children are more often admitted to hospital than other children. ${ }^{67}$ Communication in hospital can be particularly challenging for children with learning disabilities, ${ }^{8}$ and those who use augmentative and alternative communication. ${ }^{9}$ It has been reported that parents often feel unable to leave such children because of concerns about communication. ${ }^{10-13}$ When communication is poor, children and parent carers may not understand their choices and have inadequate opportunity to engage in decision-making.

Synthesis of qualitative research on the experience of disabled children as inpatients suggested that communication mediates many aspects of their experience, but is often inadequate in practice. ${ }^{14}$ Communication was found to be an overarching theme, with impact on other factors and influenced the hospital experience as a whole. Good communication can help to alleviate adverse emotional states, contribute to a more positive perception of the environment and improve confidence in staff. Further qualitative research with parents and ward staff identified key barriers and facilitators to good communication. Barriers included time pressures and the low priority given to communication; facilitators were making time to build a rapport with a child, previous experience of working with children and a family-centred outlook. ${ }^{15}$ The professional participants in our earlier qualitative study clearly expressed awareness and personal frustration with failing to meet children's communication needs. Some parents felt that their knowledge and experience of their child was not always considered or valued, which has been highlighted in previous studies. ${ }^{16}$ Our findings were similar to those of Oulton $e t a l^{8}$ which emphasised that training in caring for children with learning disabilities was a key factor in taking an individualised approach to inpatient care. ${ }^{14}$

The UK Department of Health Education Outcomes Framework includes five domains, one of which is 'NHS Values and Behaviours' and refers to healthcare staff developing values and behaviours, through training, to enhance the quality of the patient experience. ${ }^{17}$ This is a mandate for the provision of relevant training for the existing workforce.

This paper describes research to develop a training package for staff in partnership with parent carers and ward staff called 'Improving Inpatient Experiences for Disabled Children', to test the feasibility of delivery in a ward setting and to gauge the utility of such an intervention to staff.

\section{METHODS}

\section{Stakeholder involvement}

The research had a strong ethos of public involvement. We report this involvement using GRIPP2 guidance. ${ }^{18}$ Six parents of children with neurodisability from the PenCRU Family Faculty collaborated at various times to develop the training (www.pencru.org/getinvolved/ourfamilyfaculty). Financial acknowledgement of their time and travel expenses were reimbursed. Parent carers suggested the topic, helped design the training, suggested and facilitated invitation to the hospital Patient and Carer Experience Group, recorded their experiences for the video content and participated in meetings to reflect on the training with the facilitator. Parents are also involved in sharing the findings. The involvement of parent carers profoundly influenced the content of the training to deliver family experiences and messages. We did not have resources to plan for the meaningful involvement of young people; involving disabled young people would be desirable in future work. There was little ethnic diversity among the parents we work with; accounting for cultural differences might add another dimension to the training. Paediatricians and nurses were represented on the team and other clinicians were consulted about the design of the intervention.

\section{Ethics statement}

The Royal Devon and Exeter NHS Foundation Trust Research and Development Office approved the study. The Health Research Authority does not require ethics approval for studies involving NHS staff as research participants by virtue of their professional role (www.hra. nhs.uk/resources/before-you-apply/research-requiringnhs-rd-review-but-not-ethical-review).

\section{Theoretical underpinning}

The process of developing the training was informed by intervention mapping. ${ }^{19}$ Intervention mapping includes six iterative steps for developing and evaluating health interventions (table 1). This study describes the use of the first four steps to design the intervention. We took account of recommendations from the National Institute for Health and Care Excellence (NICE) guidance on behaviour change ${ }^{20}$ and the Template for Intervention Description and Replication ${ }^{21}$

\section{Step 1: Needs assessment}

The first step in intervention mapping involves assessing the need for an intervention. The research was initiated by a parent approaching the researchers following a difficult inpatient experience with their disabled child. A structured review confirmed that the inpatient experience of disabled children is not always optimal and that communication is a key determinant of inpatient experience. ${ }^{14} \mathrm{~A}$ qualitative study was undertaken to explore the experiences of families of disabled children and ward staff and to gain a fuller understanding about the concerns, skills and resources influencing communication. Fifteen parents and 25 ward staff took part in semistructured interviews or focus groups. Difficulty was experienced in recruiting children and evaluating their experiences, despite considerable efforts. Thematic analysis of the interviews and focus groups identified barriers 


\begin{tabular}{|c|c|}
\hline Products & Tasks \\
\hline $\begin{array}{l}\text { Step } 1 \\
\text { Needs } \\
\text { assessment }\end{array}$ & $\begin{array}{l}\text { Establish a stakeholder group } \\
\text { Conduct needs assessment } \\
\text { Assess capacity } \\
\text { Determine programme outcomes }\end{array}$ \\
\hline $\begin{array}{l}\text { Step } 2 \\
\text { Programme } \\
\text { objective } \\
\text { matrices }\end{array}$ & $\begin{array}{l}\text { State expected changes in behaviour } \\
\text { and environment } \\
\text { State performance objectives } \\
\text { Specify modifiable determinants } \\
\text { Create a logic model of change }\end{array}$ \\
\hline $\begin{array}{l}\text { Step } 3 \\
\text { Theory-based } \\
\text { methods } \\
\text { and practical } \\
\text { strategies }\end{array}$ & $\begin{array}{l}\text { Review programme ideas with } \\
\text { representative participants } \\
\text { Identify relevant theories } \\
\text { Choose programme methods } \\
\text { Select or design strategies } \\
\text { appropriate to change objectives }\end{array}$ \\
\hline $\begin{array}{l}\text { Step } 4 \\
\text { Programme }\end{array}$ & $\begin{array}{l}\text { Consult intended participants and } \\
\text { implementers } \\
\text { Create programme scope, sequence } \\
\text { and resources list } \\
\text { Develop design documents } \\
\text { Review available programme materials } \\
\text { Draft programme materials } \\
\text { Pretest programme materials with } \\
\text { target group and implementers. } \\
\text { Produce materials and protocols }\end{array}$ \\
\hline $\begin{array}{l}\text { Step } 5 \\
\text { Adoption and } \\
\text { Implementation } \\
\text { Plan }\end{array}$ & $\begin{array}{l}\text { Identify potential adopters and users } \\
\text { Specify adoption, implementation and } \\
\text { sustainability performance objectives } \\
\text { Specify determinants and create a } \\
\text { matrix of change objectives } \\
\text { Select methods and strategies } \\
\text { Design interventions for adoption and } \\
\text { implementation }\end{array}$ \\
\hline $\begin{array}{l}\text { Step } 6 \\
\text { Evaluation plan }\end{array}$ & $\begin{array}{l}\text { Develop evaluation model } \\
\text { Develop indicators and measures } \\
\text { Specify evaluations designs } \\
\text { Write an evaluation plan }\end{array}$ \\
\hline
\end{tabular}

and facilitators to effective communication on children's wards. ${ }^{15}$

There was no formal-specific training in the hospital focusing on communication or disability. A consultation meeting with staff representative of those requiring training informed the needs assessment to take account of the social and environmental context of the intervention. This explored interest in the training topic, practical considerations that might influence participation.

\section{Step 2: Identifying outcomes and change objectives}

The second step involved considering the objectives of training and creating a logic model of change (figure 1). The ultimate outcome is to improve the inpatient experience of disabled children through enhanced ward staff communication with disabled children and their parent carers. However, this outcome is dependent on many intermediary variables. The more proximal objectives involve who and what needs to change in order to achieve this.

The intended participants were staff who interact with children admitted to the ward. The child's journey through the ward was considered, including all interactions beyond medical and nursing care; for example, from first booking in with the ward administrator, meal times and meeting ward housekeeping staff. The target behaviour change was that ward staff prioritise and practice good communication with disabled children. Based on our needs assessment and consultation with parents in our advisory group four key practices were identified:

1. Ask the parent or carer for advice about how to communicate with their child.

2. Identify how a child communicates yes and no.

3. Communicate directly with a child when appropriate.

4. Feel comfortable to admit when you don't know the best way to communicate.

It was evident that for the intervention to succeed, organisational and cultural changes were required to support individual behaviour change. A key contextual factor was for managers to recognise and prioritise the need for training and enable staff attendance.

\section{Step 3: theory-based methods and practical strategies}

The third stage of intervention mapping is to select practical methods and strategies consistent with behaviour change theories. With reference to the NICE guidance, the theories selected as being most appropriate were the Theory of Planned Behaviour ${ }^{22}$ and Bandura's construct of self-efficacy. ${ }^{23}$ Azjen's theory states that intention is the main determinant of action, this is predicted by attitude, subjective norm and perceived behavioural control. In Bandura's construct, self-efficacy is the belief in one's ability to succeed in specific situations. Table 2 lists the learning objectives for ward staff and how each links with behaviour change concepts and the content of the training.

Common principles of adult learning were applied, for example, the concept of experiential learning and learning as a social activity. Continuous Professional Development tends to be more effective when time is allocated to reflect on learning and where organisational support is provided to facilitate change. ${ }^{24}$ This supports the importance of the secondary stream of the intervention; cultural and organisational change to support and maintain individual behaviour change.

\section{Step 4: Programme development}

This step produces the content and delivery of the intervention. Our consultation with ward staff suggested (1) it should not last more than 1 hour; (2) it should not be 'mandatory training' as this may mean some people attend reluctantly and (3) a face-to-face group session was preferred to online learning.

It was agreed with the advisory group that in order for the training to be sustainable and reproducible, videos of parents would be used to deliver key messages rather 


\begin{tabular}{|c|c|c|c|c|c|}
\hline Rationale & $\Rightarrow$ & ention & Mediators & $\Rightarrow$ & omes \\
\hline Needs assessment & Content & Delivery & Determinants & $\begin{array}{c}\text { Programme } \\
\text { outcomes }\end{array}$ & Final outcomes \\
\hline $\begin{array}{l}\text { - Poor inpatient } \\
\text { experience for disabled } \\
\text { children } \\
\text { - Communication is a key } \\
\text { determinant of inpatient } \\
\text { experience } \\
\text { - Ward staff find } \\
\text { communicating with } \\
\text { disabled children } \\
\text { challenging } \\
\text { - NHS policy prioritises } \\
\text { enhancing patient } \\
\text { experience as an } \\
\text { outcome of learning and } \\
\text { development for staff }\end{array}$ & \begin{tabular}{|l} 
Training to: \\
- Convey 4 key \\
practices to \\
improve \\
inpatient \\
experience \\
- Cultivate \\
empathy \\
- Develop \\
confidence \\
- Identify local \\
resources \\
- Raise \\
awareness \\
within the \\
organisation
\end{tabular} & $\begin{array}{l}\text { - Targets } \\
\text { collective ward } \\
\text { culture } \\
\text { - Peer delivered } \\
\text { - Video clips of } \\
\text { parents' } \\
\text { experiences } \\
\text { - Scripted } \\
\text { manual for } \\
\text { facilitators } \\
\text { - Small group } \\
\text { discussion } \\
\text { - One off session } \\
\text { - Low resource }\end{array}$ & \begin{tabular}{|l} 
- Attitudes, \\
including empathy, \\
priority \& \\
responsibility \\
- Self-efficacy \\
- Peer support \\
- Relationship \\
history with \\
patient/parent \\
carers \\
- Information \\
sharing practices
\end{tabular} & $\begin{array}{l}\text { Prioritisation \& } \\
\text { practice of good } \\
\text { communication by } \\
\text { ward staff }\end{array}$ & $\begin{array}{l}\text { Improved inpatient } \\
\text { experience for } \\
\text { disabled children }\end{array}$ \\
\hline
\end{tabular}

Figure 1 Logic model of the training intervention and outcomes. NHS, National Health Service.

than parent facilitators. The facilitators would be local staff; in this instance the sessions were delivered by a paediatric registrar and a paediatric nurse with experience of working with disabled children. It was perceived that a nurse cofacilitator made the training more accessible to nurses who comprise the majority of ward staff.

Personal and external factors influencing running sessions successfully were identified; this informed development of delivery strategies for the training (table 3). Advertising strategies were considered to ensure that all ward staff were made aware of the training. Faceto-face recruitment on the ward promoted discussion of the training and peer support to attend. Discussion with ward managers from different disciplines supported staff in attending. For example, an agreement was reached for nursing staff to use their half-hour lunch break and be

\begin{tabular}{|c|c|c|}
\hline Learning objectives & Behaviour change concepts & Training content \\
\hline $\begin{array}{l}\text { To understand the impact of } \\
\text { communication behaviours on } \\
\text { disabled children }\end{array}$ & $\begin{array}{l}\text { Outcome expectancies and } \\
\text { positive attitude } \\
\text { Personal and moral norms }\end{array}$ & $\begin{array}{l}\text { Parent video's describing their child's experience } \\
\text { and how this could have been improved } \\
\text { Inclusion of a positive experience } \\
\text { Handouts including research findings }\end{array}$ \\
\hline $\begin{array}{l}\text { To be motivated to change } \\
\text { behaviour }\end{array}$ & $\begin{array}{l}\text { Personal relevance } \\
\text { Self-efficacy }\end{array}$ & $\begin{array}{l}\text { Interactive tasks appropriate to role, small group } \\
\text { discussion of personal experience } \\
\text { Parent videos }\end{array}$ \\
\hline To develop empathy & - Personal and moral norms & $\begin{array}{l}\text { - Opportunity for personal and small group reflection } \\
\text { - Practical exercises } \\
\text { - Parent videos }\end{array}$ \\
\hline $\begin{array}{l}\text { To feel capable of behaviour } \\
\text { change }\end{array}$ & $\begin{array}{l}\text { Self-efficacy } \\
\text { Prompt/cue }\end{array}$ & $\begin{array}{l}\text { Four key practices, reinforced throughout training } \\
\text { - Basic awareness of some communication aids } \\
\text { Signposting to local resources and policies } \\
\text { - Poster of four key practices displayed on ward }\end{array}$ \\
\hline $\begin{array}{l}\text { To make a commitment to } \\
\text { change }\end{array}$ & $\begin{array}{l}\text { Intention formation } \\
\text { Concrete plans }\end{array}$ & $\begin{array}{l}\text { Opportunity to document how the training will } \\
\text { change personal practice }\end{array}$ \\
\hline $\begin{array}{l}\text { To feel supported by the } \\
\text { organisation in changing } \\
\text { behaviour }\end{array}$ & $\begin{array}{l}\text { Knowing and utilising existing } \\
\text { processes and service models }\end{array}$ & $\begin{array}{l}\text { 'Local slot': highlighting local policies and useful } \\
\text { resources }\end{array}$ \\
\hline
\end{tabular}


Table 3 Strategies for delivery objectives

\begin{tabular}{|c|c|c|c|}
\hline Delivery objectives & Personal factors & External factors & Strategies \\
\hline $\begin{array}{l}\text { Raised awareness at } \\
\text { organisational level } \\
\text { with 'buy in' to cultural } \\
\text { change }\end{array}$ & $\begin{array}{l}\text { Perceived } \\
\text { importance of the } \\
\text { need for training }\end{array}$ & $\begin{array}{l}\text { Competing interests } \\
\text { and priorities }\end{array}$ & $\begin{array}{l}\text { Meeting with the hospital Patient Carer } \\
\text { Experience Group } \\
\text { Highlighting statutory requirements } \\
\text { Reviewing policies and strategies at children's } \\
\text { ward business meeting }\end{array}$ \\
\hline $\begin{array}{l}\text { Everyone working on } \\
\text { the ward are able to } \\
\text { attend training }\end{array}$ & $\begin{array}{l}\text { Knowledge of } \\
\text { training sessions }\end{array}$ & $\begin{array}{l}\text { Allocation of time to } \\
\text { attend (behavioural } \\
\text { control) } \\
\text { Accessibility of site } \\
\text { Duration of training } \\
\text { and timing in day }\end{array}$ & $\begin{array}{l}\text { Meeting with senior staff from all disciplines to } \\
\text { agree permission to attend } \\
\text { Identifying a suitable site } \\
\text { Delivering the training at acceptable timings and } \\
\text { duration to allow equity of access }\end{array}$ \\
\hline $\begin{array}{l}\text { Everyone working } \\
\text { on the ward attends } \\
\text { training }\end{array}$ & $\begin{array}{l}\text { Confidence to } \\
\text { attend } \\
\text { Motivation to attend }\end{array}$ & $\begin{array}{l}\text { Modelling by peers } \\
\text { who have attended } \\
\text { (subjective norms) }\end{array}$ & $\begin{array}{l}\text { Visiting the ward and speaking to staff about the } \\
\text { training } \\
\text { Signing up peers to attend together } \\
\text { Providing lunch as a motivator } \\
\text { Identifying key figures and encouraging them to } \\
\text { attend }\end{array}$ \\
\hline
\end{tabular}

given an additional half hour to enable them to attend the full-hour session.

The training included a warm up activity to engage participants, parent videos, interactive tasks and small group discussion. Time was allocated at the end for personal reflection, to document a commitment to behaviour change and to provide feedback. Participants were asked for numerical scores for training elements and to identify two positive points, two areas for improvement and how the session was likely to change their practice. After each session the facilitators reviewed the feedback and proposed changes together, this was also discussed with the advisory group.

\section{RESULTS}

Eighty participants attended one of four sessions at the Royal Devon and Exeter NHS Foundation Trust, which is a UK University Hospital. All sessions were attended by various staff (table 4). Allied health professionals included physiotherapists, play therapists, dieticians, a pharmacist and a speech and language therapist. Non-clinical staff included housekeeping and catering staff, administrators, teachers and chaplain. A notable feedback comment was that 'it felt very powerful to have such a cross section of staff and hierarchy all working at the same task'.

The first session was attended by 26 people, including some unbooked participants. Subsequent sessions were strictly limited to 20. One session had fewer numbers at short notice due to unexpected clinical workload and staff capacity. Participant feedback was very positive, with high satisfaction scores for all areas. Comments in response to asking for positive points indicated that the videos and practical strategies designed to develop empathy and understand the impact of communication behaviours on disabled children had been successful. Comments in response to the question 'How will you change your practice?' indicated that participants were willing to make a commitment to change, felt capable of change and were assimilating key messages (box 1).

Feedback on areas for improvement included allowing more time for discussion and highlighting parents' positive and negative experiences. This resulted in the inclusion of a positive parent experience video and distributing background information prior to the session rather than during it, to allow more discussion time. One suggestion was for prompts and reminders to be displayed on the ward. We worked with young people with learning disability at a local further education college to create a poster that provides ' 4 Top Tips' to improve communication with disabled children.

\begin{tabular}{lll}
\hline Table 4 & Roles of participants attending training \\
\hline Profession & $\begin{array}{l}\text { Number of } \\
\text { participants }\end{array}$ & Roles represented \\
\hline Medical & 34 & $\begin{array}{l}\text { Seven consultants, 20 junior } \\
\text { doctors, seven medical } \\
\text { students }\end{array}$ \\
\hline Nursing & 25 & $\begin{array}{l}\text { Four senior nurses, four } \\
\text { specialty (epilepsy, oncology), } \\
10 \text { ward nurses, five nursing } \\
\text { students, two nursing } \\
\text { assistants }\end{array}$ \\
\hline $\begin{array}{l}\text { Allied health } \\
\text { professionals }\end{array}$ & 9 & $\begin{array}{l}\text { Three physiotherapists, two } \\
\text { play therapists, two dieticians, } \\
\text { one pharmacist, one speech } \\
\text { and language therapist }\end{array}$ \\
Ward- non- & 12 & $\begin{array}{l}\text { Six housekeeping and } \\
\text { catering staff, two ward } \\
\text { administrators, 1 chaplain and } \\
\text { three teachers }\end{array}$ \\
\hline
\end{tabular}




\section{Box 1 Examples of feedback}

\section{Positive points}

'Easy understanding by watching interviews'

'Really improved the level of understanding of how children can feel in some situations'

'Sharing experiences was helpful'

'Practical exercises were enlightening'

\section{Areas for improvement}

'More discussion'

'Focus less on problems'

'Some slides text heavy'

'Room too hot and crowded'

\section{How will you change your practice?}

'Considering the patient as an individual'

'Feel more confident to just ask'

'Take more time to think'

'More techniques on how to communicate'

\section{DISCUSSION}

The training was well received in the context of a university hospital paediatric ward. The number of staff attending and the breadth of roles represented reflect successful recruitment strategies and a high level of interest in improving ward communication with disabled children. Strategies to raise awareness with 'buy in' to cultural change at management level were an essential part of the intervention. The commitment to wider cultural change was underpinned by the involvement of stakeholder groups and promotion at ward and hospital level meetings.

The iterative approach of intervention mapping provided a structure to consider the complexity of personal and external determinants that influence behaviour at an individual and organisational level. Consultation provided guiding principles for an acceptable delivery model for training; feedback after sessions led to more focused content and staff feedback indicates provisional willingness and motivation to change behaviour. The intervention mapping process was useful as an approach, however, we found applying it in practice to be time-consuming as it required granular levels of analysis in steps 2 and 3 to define objectives. We followed the approach insofar as it was possible within the limitations of time and resources available. An alternative approach proposing six steps in intervention development, ${ }^{25}$ may be more practical and be sufficient for the needs of future research when the high degree of rigour required by intervention mapping is not feasible.

A high level of commitment and enthusiasm was required by the paediatric registrar to encourage management support for staff participation. Strategic recruitment of influential staff, seeking validation from credible advocates and peer encouragement through word of mouth were vital to recruitment. This approach relied heavily on understanding the social dynamics of the ward. The commitment to cultural change in the hospital benefited from high-level support from the Parent and Carer Experience Group and seizing opportunities to raise the training at ward meetings. While it is difficult to identify the impact of these individual and local contextual mediators, we suggest that the professional leading these initiatives needs to know the key people in their own organisation.

Despite the relative success of delivering this initiative in one hospital, we accept the need for replication in other hospitals, and formal evaluation of the effectiveness of the intervention to actually improve children's experience of care as inpatients. The transferability of the intervention to other hospitals will help to identify which intervention ingredients can influence organisational and cultural change on a broader scale. The hospital ward is a complex environment with a host of interacting variables. The premise of the logic model underpinning the intervention is that delivering training will lead to communication behaviour change in staff and that this will improve the disabled children's experience of care as inpatients. This ultimate outcome could be measured using questionnaires developed to measure children's experience as inpatients. ${ }^{26}{ }^{27}$ However, before proceeding to such a study, we need to refine the intervention content and be confident in the delivery strategies that it is feasible for the training to be delivered in hospital children's wards.

Our training was designed to specifically address challenges to communication that arise on a paediatric ward. The group learning resources offered by disability matters are a potentially more comprehensive means to address the learning needs of professionals working with disabled children and young people across different settings. ${ }^{28}$ A Danish study incorporated communication skills into clinical practice using face-to-face methods in a 3-day course. We suggest that this time commitment is unlikely to be realistic in many acute settings. ${ }^{29} \mathrm{~A}$ strength of this training package is that it was designed purposefully to be short, sustainable and deliverable with minimal resources.

A report by the Care Quality Commission (CQC) in England highlighted inequalities of inpatient experience for children with physical, learning or mental health needs. ${ }^{30}$ There was a call for action by representatives of the CQC, NHS England, professional bodies (RCPCH) and third sector advocacy groups (Young Minds). The importance of good communication was emphasised. These inequalities have persisted despite international and national legislation and ground level hospital policies and procedures. This agenda can be lost during the day-to-day ward pressures, but this is not acceptable. This intervention provides a low cost, fixed time, minimal resource option to raise awareness at organisational level and provides staff with training that is based on parental and child experiences, to motivate behaviour change. We have shown that it is feasible to deliver and that it was 
well received by staff. Early feedback was encouraging and indicated a real desire among staff to improve their communication skills. The next stage will be to test the transferability to other settings and to formally evaluate its impact. We believe that there is much potential for this intervention to improve the hospital inpatient experience of disabled children.

Acknowledgements The authors thank all parents involved in developing the intervention. We are particularly grateful to Bel McDonald, Julia Melluish and Mike Hurley who were interviewed for the videos, Jon Toomey for producing the films and Sheri 0stler for enabling access to the Parent and Carer Experience group. Thank you also to staff of Bramble Ward, Royal Devon and Exeter NHS Foundation Trust that participated in the study, and to the Exeter College students that produced the poster with Katharine Fitzpatrick our Family Involvement Coordinator We are also grateful to Sharon Blake for helping to finalise the manual and videos.

Contributors All authors made substantive intellectual contributions to the study. $\mathrm{RG}$ and $\mathrm{CM}$ drafted the manuscript, all coauthors reviewed and revising it critically for important intellectual content and approved the final version.

Funding The study was part funded by a small grant from the Royal Devon \& Exeter Foundation NHS Trust. PenCRU receives financial support from the charity Cerebra and the National Institute for Health Research (NIHR) Collaboration for Leadership in Applied Health Research and Care of the South West Peninsula (PenCLAHRC)

Disclaimer The views expressed in this publication are those of the authors and do not necessarily represent the views of Cerebra, the NHS, the NIHR or the Department of Health.

Competing interests None declared.

Provenance and peer review Not commissioned; externally peer reviewed.

Open Access This is an Open Access article distributed in accordance with the terms of the Creative Commons Attribution (CC BY 4.0) license, which permits others to distribute, remix, adapt and build upon this work, for commercial use, provided the original work is properly cited. See: http://creativecommons.org/ licenses/by/4.0/

(C) Article author(s) (or their employer(s) unless otherwise stated in the text of the article) 2017. All rights reserved. No commercial use is permitted unless otherwise expressly granted.

\section{REFERENCES}

1 United Nations. Convention on the rights of the child. New York: United Nations, 1989.

2 United Nations. Convention on the rights of persons with disabilities. Resolution 60/232. New York: United Nations, 2006.

3 Department of Health. Getting the right start: national service framework for children. Standard for hospital services. $2003 \mathrm{http}: / /$ www.nhs.uk/nhsengland/aboutnhsservices/documents/nsf\% 20children\%20in\%20hospitlaldh_4067251[1].pdf (accessed May 2017).

4 Care Quality Commission. Health care for disabled children and young people. A review of how the health care needs of disabled children and young people are met by the commissioners and providers of health care in England. 2012 https://www.cqc.org.uk/ sites/default/files/documents/health_care_for_disabled_children.pdf (accessed May 2017).

5 Department of Health. NHS outcomes framework. $2016 \mathrm{https}: / /$ www.gov.uk/government/publications/nhs-outcomes-framework2016-to-2017 (accessed May 2017).

6 Spencer NJ, Lewis MA, Logan S. Diagnostic and socio-demographic changes in multiple hospital admission in children under two over a five-year period. J Public Health Med 1993;15:332-6.
7 Mahon M, Kibirige MS. Patterns of admissions for children with special needs to the paediatric assessment unit. Arch Dis Child 2004;89:165-9.

8 Oulton K, Sell D, Kerry S, et al. Individualizing hospital care for children and young people with learning disabilities: it's the little things that make the difference. J Pediatr Nurs 2015;30:78-86.

9 Phua V, Reid SM, Walstab JE, et al. Inpatient care of children with cerebral palsy as perceived by their parents. $J$ Paediatr Child Health 2005;41:432-6.

10 Coyne I. Consultation with children in hospital: children, parents' and nurses' perspectives. J Clin Nurs 2006;15:61-71.

11 Avis M, Reardon R. Understanding the views of parents of children with special needs about the nursing care their child receives when in hospital: a qualitative study. J Child Health Care 2008;12:7-17.

12 Finke EH, Light J, Kitko L. A systematic review of the effectiveness of nurse communication with patients with complex communication needs with a focus on the use of augmentative and alternative communication. J Clin Nurs 2008;17:2102-15.

13 Oulton K, Heyman B. Devoted protection: How parents of children with severe learning disabilities manage risks. Health Risk Soc 2009:11:303-19.

14 Shilling V, Edwards V, Rogers M, et al. The experience of disabled children as inpatients: a structured review and synthesis of qualitative studies reporting the views of children, parents and professionals. Child Care Health Dev 2012;38:778-88.

15 Sharkey S, Lloyd C, Tomlinson R, et al. Communicating with disabled children when inpatients: barriers and facilitators identified by parents and professionals in a qualitative study. Health Expect 2016:19:738-50.

16 Hewitt-Taylor J. Parents whose children have complex needs: experiences of hospitalization. Journal of Children's and Young People's Nursing 2008;2-13-19.

17 Department of Health. The Education outcomes framework. 2013 https://www.gov.uk/government/publications/education-outcomesframework-for-healthcare-workforce (accessed May 2017).

18 Staniszewska S, Brett J, Simera I, et al. GRIPP2 reporting checklists: tools to improve reporting of patient and public involvement in research. BMJ 2017;358:j3453.

19 Eldredge L, Markham C, Kok G, et al. Planning health promotion programs: an intervention mapping approach. John Wiley \& Sons 2016.

20 NICE (internet). Behaviour change: general approaches. 2007 https://www.nice.org.uk/Guidance/ph6 (accessed May 2017).

21 Hoffmann TC, Glasziou PP, Boutron I, et al. Better reporting of interventions: template for intervention description and replication (TIDieR) checklist and guide. BMJ 2014;348:g1687.

22 Ajzen I. The theory of planned behavior. Organ Behav Hum Decis Process 1991;50:179-211.

23 Bandura A. Self-efficacy: the exercise of control. New York: Freeman, 1997.

24 Mathers N, Mitchell C, Hunn A. A study to assess the impact of continuing professional development (CPD) on doctors' performance and patient/service outcomes for the GMC: Capita Business Services Limited, 2012:1-41.

25 Wight $\mathrm{D}$, Wimbush $\mathrm{E}$, Jepson $\mathrm{R}$, et al. Six steps in quality intervention development (6SQuID). J Epidemiol Community Health 2016;70:520-5

26 Toomey SL, Zaslavsky AM, Elliott MN, et al. The development of a pediatric inpatient experience of care measure: child HCAHPS. Pediatrics 2015;136:360-9.

27 Ziniel SI, Connor JA, Graham D, et al. Development and psychometric characteristics of the pediatric inpatient experience survey (PIES). Int J Qual Health Care 2016;28:191-9.

28 Disability Matters.org.uk (internet). Disability matters learning resources. https://www.disabilitymatters.org.uk/ (accessed May 2017).

29 Ammentorp J, Kofoed PE, Laulund LW. Impact of communication skills training on parents perceptions of care: intervention study. $J$ Adv Nurs 2011:67:394-400.

30 Care Quality Commission. Children and young people's inpatient and day case survey. 2014 http://www.cqc.org.uk/sites/default/files/ 20150630_cypsurvey_keyfindings.pdf (accessed May 2017). 